UDC 539.3;624.1

\title{
SCIENTIFIC SUBSTANTIATION OF ENGINEERING PREPARATION MEASURES DUE TO THE INFLUENCE OF CONSTRUCTION IN THE DENSE BUILDING CONDITIONS
}

\author{
D.E. Prusov \\ Doct.Tech.Sci, Prof.Dr.Habil. \\ Kyiv National University of Construction and Architecture \\ Institute of Innovative Education \\ 03037, Ukraine, Kyiv, Osvity str., 4; (+38 044) 244-96-63, 245-48-56 \\ E-mail:prusov.de@knuba.edu.ua
}

DOI: $10.32347 / 2410-2547.2020 .104 .229-241$

\begin{abstract}
The method of studying the stress-strain state of reinforcement structures of combined soil massifs has been proposed with the geometric and physical nonlinearity in the formulation of the problem based on the nonlinear theory of elasticity and plasticity of the soil. The study of the stressdeformed state of the computational domain from the standpoint of the mechanics of the deformed solid body had been carried out, using algorithms for solving the problems of the theory of elasticity and plasticity, with the construction of universal computational models of the combined half-space, that allows to determine more reasonably the magnitude of the stress-strain state of complex soil bases in interaction with the reinforcement structures, the surrounding buildings foundations and the whole complex of the surrounding buildings structures. The influence of new construction on the condition of soil bases and foundations of adjacent buildings had been evaluated by determining the change of pressure on the reinforcement structure and determining the stress-strain state change of this structure and the foundation of the existing house. The change in the deformation of the foundation of the existing building, ie the oscillation of the soil foundation and the maximum amplitude of uneven subsidence of the foundations of the existing building have been determined. Each formulation of the problem had to include its own reliability analysis and a specific approach that requires numerical modeling and development of appropriate measures to scientifically substantiate engineering preparation measures in dense building. Further design of protective reinforcement structures for new construction under the conditions of the building reconstruction has carried out considering the impact on the existing buildings and structures and the adjacent soil mass of different stages of construction, begining with the arrangement of protective reinforcement structures, the development of a excavation due to the effect of unloading the foundation, and the sequence of erection of engineering structures.
\end{abstract}

Keywords: new construction, scientific substantiation, stress-strain state, reinforcement structures, engineering preparation.

Introduction. In the process of reconstruction of urban territories by carrying out new construction in the conditions of dense construction, in particular, large-scale use of underground space in difficult engineeringgeological conditions, the activation of additional processes in the soil bases of territories and foundations of existing buildings and structures had been revealed. Research of the interaction of soil bases with the objects of existing construction in the process of reconstruction of districts are associated with the determination of the stress-deformed state and stability of the soil massif, and the determination of the deformability and strength of the structures of its strengthening. Estimation of the stress state of the half-space involves

(C) Prusov D.E. 
comparing the results of the calculation with the maximum permissible deformations and displacements, ie, possible local areas of loss of stability and development of plastic deformations, that is, reaching the boundary condition of the soil bases in the continuous development of shear deformations.

Problems of designing enclosing structures of deep ditches in the conditions of dense building. Tasks for the study of enclosure constructions should be solved with the simultaneous combination of such scientific directions as nonlinear theory of elasticity and plasticity, nonlinear soil mechanics, structural mechanics of combined structures, engineering geology, calculation of foundations and foundations of deep formation, also studies of the behavior of structures of existing buildings and structures under changed conditions.

Development of theoretical bases for the study of large elastic and elasticplastic deformations of a continuous medium, mathematical modeling of its joint work with structures of buildings and structures, the study of the tense state and the development of calculation methods, the influence of engineeringgeological conditions on the processes of reconstruction, issues of engineering and engineering a lot of work is devoted to the development of the theory of reliability, however, the application of any single theory or methodology does not allow to study all aspects of engineering ovky, the whole complex of factors influence the reconstruction of existing urban areas typically associated with the construction of new facilities, insufficiently studied soil deformation processes in the fundamentals surrounding dense housing structures in complex geological conditions. All this requires the development and improvement of special theoretical, constructive and planning decisions on the scientific substantiation of the reconstruction, the creation and development of effective methods of mathematical modeling and scientific research of engineering preparation objects, which most fully take into account the specifics of the interaction of structures with soil semi-space scientific analysis of the possible volume of reconstruction, as well as the creation of appropriate concepts for consideration the impact of new construction in dense building and predicting its consequences, which generally determine the priorities of modern civil engineering.

Thus, in order to solve similar problems and scientific and technical substantiation of urban reconstruction decisions under the above conditions, it is necessary to combine the mentioned sciences of the construction industry within the framework of continuous environment mechanics in the general formulation, that is, considering geometric and physical nonlinearities, states at different stages of deformation of inhomogeneous materials, interaction of multimodal materials, solids with a continuous elastic-plastic environment, etc. Therefore, the complex problem of boundary equilibrium of the soil massif in a flat formulation with wall-to-soil enclosing structures, structures of reinforcement of inhomogeneous multilayer soil masses, shallow foundations, pile foundations, and foundations has been considered. 
Methodology for the condition research of the enclosure structures in interaction with the soil semi-space. Therefore, to carry out a reliable analysis of the degree of new construction impact on the state of the foundations of adjacent existing buildings, it is necessary to solve a complex scientific problem related to the methods of continuum mechanics in the most general approach. The solution to this complex problem tasks associated with the development of a research methodology combined space and the interaction of solid deformable bodies from the soil mass, based on the laws of the nonlinear theory of elasticity and plasticity, nonlinear soil mechanics, variational methods, apparatus connecting nonlinear programming, efficient numerical methods - finite element method - attached to discretization in space, and finite difference method attached to discretization in time [3].

Determination of the stress-strain state of a ditch fence, foundation soil and structures located near the ditch, is carried out on the basis of solving the problems of soil mechanics, in which real soil is replaced by a specific model [7]. To carry out researches the impact on the stress-strain state of the foundations and foundations of adjacent buildings the methodology for modeling the interaction of enclosure structures with inhomogeneous soil semispace has been developed based on a nonlinear theory of elasticity and plasticity, advanced mechanical model of soil semi-space stability, considering the extended fluidity criterion, developed basic relationships of the finite element method, based on an efficient scheme with geometric and physical nonlinearity in the formulation of the problem $[1,2]$.

A flat problem of nonlinear elasticity theory about interaction of a fence structure with soil space is considered. The formulation of the problem assumes discrete modeling of substantially inhomogeneous soil layers, as well as the presence of solid inclusions (which are several orders of magnitude greater than the stiffness of the soil mass layers), modeling elements of fence structures, foundation soils, and foundation structures of surrounding buildings, as well as anchors, which causes the presence of stress concentrations and the development of plastic deformations at the boundaries of elements inclusions in the soil in the first limiting state in accordance with nonlinear soil mechanics. For the calculation of local stability losses in the presence of significant displacements and continuous development in local zones of plastic deformation shifts, the problem of flat deformation of an inhomogeneous anisotropic halfspace is considered, taking into account geometric and physical nonlinearity in the formulation of the problem.

In the initial ratios of the proposed methodology, the equilibrium of a continuous medium is described by the first principle of virtual work, in the absence of restrictions on the nature of external influences, ie can be taken into account both conservative and non-conservative forces, for example, tracing forces in the conditions of geometric nonlinearity and in the presence in the presence of unilateral connections: 


$$
\int_{v}\left(\sigma^{\prime i j}+c^{i j k l}(e, p)\right) \delta \gamma_{i j} d v-\int_{v} p^{i \prime} \delta u_{i^{\prime}} d v-\int_{S} q^{i^{\prime}} \delta u_{i^{\prime}} d s=0,
$$

where $\sigma^{\prime i j}$ there are components of the initial stress tensor; $c^{i j k l}(e, p)$ there are components of the elastic tensor in the elastic-plastic state of the material; $\delta \gamma_{i j}$ there is a variation in the increment of the Cauchy-Green finite deformation tensor; $p^{i \prime}, q^{i \prime}$ there are components of generalized vectors of volume and surface forces in a global Cartesian coordinate system; $\delta u_{i^{\prime}}$ there are variations of the vector components of the increments of displacements in the global coordinate system.

Variational equation (1) is described in increments of displacements, strains and stresses when the initial state is natural, that is, the stresses are zero, and describes the equilibrium elementary volume (finite element) of an arbitrary continuous medium in accordance with the energy methods of the problem solving approach, regardless of its physical properties, it is adequate to such a stress state, when a small additional influence can disturb the equilibrium. This stress state is also characterized by the fact that the shear resistance in the elementary region (finite element) is determined in the limit state for this type of soil. This condition relates to the second phase of the boundary states of the soil with a significant development of shear deformations in the soil massif [8].

In the proposed method of solving the problems of soil mass stability, the criterion of soil stability or fluidity in a separate homogeneous isotropic elementary region (finite element) is described in a universal form (in the form of stress invariants) based on the Mises extended fluidity criterion, which also includes the Coulomb-Mohr principle, when the intensity of stress is described by hydrostatic pressure, considering the angle of internal friction $(\operatorname{tg} \varphi)$ and soil adhesion values $(c)$, and taking into account not only the second but also the third invariant of the tensor-deviator of the stress functions through the LodeNadai invariant:

$$
\begin{gathered}
f\left(\notin, \S, \bar{\phi}^{(P)}, \alpha, \varphi, c\right)=\frac{3}{2} I_{1}\left(\oiint^{2}\right)\left(\cos \alpha-\frac{1}{\sqrt{3}} \sin \alpha \cdot \sin \varphi\right)^{2}- \\
-\left[\frac{1}{\sqrt{3}} I_{1}(€) \sin \varphi-\sqrt{3} c \cdot \cos \varphi\right]^{2}=0 ; \\
\alpha=\frac{1}{3} \arcsin \left\{-\sqrt{6} \frac{I_{1}\left(\oiint^{3}\right)}{\left.\left[I_{1}\left(\oiint^{2}\right)\right]^{\frac{3}{2}}\right\},}\right.
\end{gathered}
$$

where $€, \Subset, \S^{(P)}$ there are tensors of general (total) stresses, stresses of the deviatorial part and plastic deformations, respectively; $I_{1}\left(\S^{2}\right), I_{1}\left(\S^{33}\right)$ there are 
the first invariants of the square and the cube of the stress tensor; $\varphi, c$ there are angle of internal friction and specific soil adhesion respectively.

Thus, the theory of plastic flow, which is based on the construction of differential relations between stresses and strains or in the form of increments, allows to perform modelling the materials elastic-plastic behavior more accurately. The plasticity phenomenon, which depends on the load history, needs to calculate the derivatives and increments of plastic deformation over the entire load history, with subsequent integration of the accumulated stresses. The surface of plasticity is a surface of fluidity that for hardening materials can change as the stress state changes. Negative values of the load function correspond to the elastic region. During unloading the plastic deformation increment and the Odquist plasticity parameter are zero and the incomplete differential of the loading function is less than zero. Under neutral loading, the stress state is on the elasticity border and no change in the plasticity surface occurs. For numerical researches of the soil massif stability, the variational equilibrium equations (1) and the load surface equation in the six-dimensional stress space (2) can be used as the initial ratios in the proposed methodology.

Thus, the proposed theory is a development of the theory of the boundary stress state of the soil half-space based on the introduction of an extended yield criterion for a flat problem of nonlinear theory of elasticity and plasticity, which involves determining the magnitude of the second critical load, in which continuous stretches of boundary stress state occur in the soil half-space.

The theory developed is based on the ideas of generalizing the dependencies of soil mechanics and consists in constructing the relations of the stress-strain state of the computational domain from the positions of the mechanics of the deformed solid, using algorithms for solving the problems of the theory of elasticity and plasticity, with the construction of universal computational models of combined half-space, which makes it possible to more accurately determine the magnitude of the stress-strain state of complex soil bases, which interact with the enclosure structures of the fortifications, the foundations of the adjoining buildings and the whole complex of structures of the surrounding building $[4,5]$. Based on these provisions, a methodology for investigating the interaction of protective protective structures with soil half-space in the transboundary state has been developed, considering the geometrical and physical nonlinearities in the problem formulation, in the implementation of the evolution of complex loading taking into account the active and passive components of the load and the effect of unloading the combined half-space, providing a more accurate account of both elastic and plastic deformations, and allows to determine more reasonably the magnitude of stress-strain state of soil bases and foundations, constructions of buildings and structures of surrounding development, which are in interaction with complex soil bases, that is, it allows to study the processes that occur in soil bases during the reconstruction of urban territory, which essentially constitute an assessment of the impact of new construction on adjacent buildings, especially in difficult engineering-geological conditions. 
Scientific substantiation of measures for engineering preparation of construction in the conditions of dense building. For the purpose of to determine the factors of influence on the existing buildings during the reconstruction of a section of urban territory in the conditions of dense housing within the framework of scientific and technical support for the design and construction of an apartment building with built-in office premises and underground parking has been performed design and calculation researches with the implementation of numerical calculations of half-space to a depth of $41.0 \mathrm{~m}$ in the central section of the study site with a length of $150.0 \mathrm{~m}$.

Numerical researches have applied the methodology of solving the problem of nonlinear soil mechanics by the boundary equilibrium of soil arrays when interacting with the enclosure structures of deep ditches and elements of foundations of new and existing buildings. The results of the combined halfspace study using a new model of the multilayer soil massif equations state have been obtained for a specific problem in the variant of the pit enclosing structure interaction with the ground half-space, and the foundations of the existing residential five-storeyed building, when the active pressure on the retaining wall in the soil exceeds the passive pressure of the soil resistance at the base of the pit under the building being designed.

The purpose of the research is to determine the change in pressure on the enclosure structure over time and to determine the change in the stress-strain state of the enclosure structure itself and the basis of the existing dwelling house. The result of determining the change in the deformation of the foundation of a 5-storey building is the fluctuation of the soil foundation and the maximum amplitude of uneven subsidence of the foundations of an existing building, which is a criterion for determining the influence of adjacent construction in conditions of dense urban development on the condition of foundations and foundations of adjacent buildings.

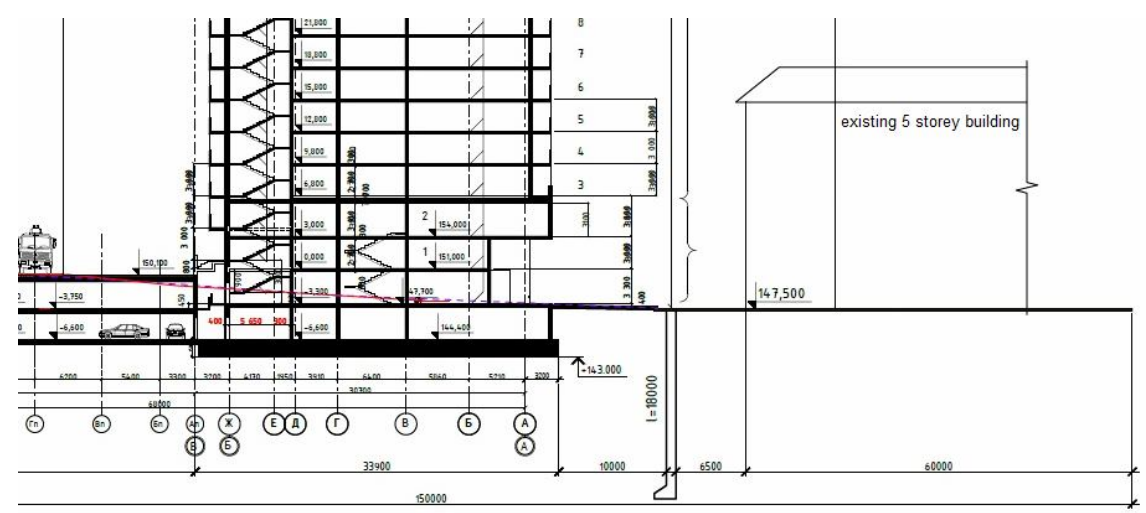

Fig. 1. The section of the projected multi-storey residential building and the existing 5 -storey residential building 
The initial data are determined physical and mechanical characteristics of the layers of soil half-space according to the data of engineering and geological surveys, considering correction of soil multilayer half-space properties in depth, as well as the physical and mechanical characteristics of inclusions in the halfspace of concrete and reinforced concrete elements, among which are piles of enclosing structures such as solid "wall in soil", grate and solid reinforced concrete foundation slab of concrete, slabs of foundations of existing buildings and concrete wall blocks.

The estimated load per 1 sq.m of the grid surface area has been determined, which is $82.32 \mathrm{kN} / \mathrm{m}^{2}$. The given load on the cutting edge of the foundations of a five-storey existing residential building is $14.22 \mathrm{kN}$ per $0.5 \mathrm{~m}$ of the length of the outer wall. A discrete model and calculation scheme of interaction of enclosing structures of the pit, pile foundations of a new residential building and the foundations of an existing dwelling house with soil half-space have been constructed.

The initial variation of the motion equation in accordance with energy methods describes the equilibrium of the elementary volume of an arbitrary continuous medium, regardless of its physical and mechanical properties. The proposed methodology implements the applied approach of variational principles and the theory of boundary stress deformed body, when the resulting solutions are related to the first distribution of elastic regions into elastic and non-elastic regions with developed zones of elastic-plastic (soil-shear) deformations. The original finite element model in the deformation process is transformed in accordance with the criterion of fluidity (destruction) of the soil array and is divided into two zones of stress-strain state determination: elastic and elastic-plastic using a Coulomb-Mohr criterion loading surface considering the tensor-deviator invariant of the stress function through the Lode-Nadai invariant [8]. The proposed methodology also uses Mises' extended modified fluidity criterion, which enables more accurate solutions to the stability problems of the combined multilayer half-space.

The discrete model and the calculation scheme of the multilayered soil halfspace were constructed taking into account the presence of inclusions of the structures of the ditches, the foundations of the new building, the existing structures and cavities.

The grid area of the discrete model $S_{1}, S_{2}, S_{3}$, is regular and placed within $S_{1}=1, M 1, S_{2}=1, M 2, S_{3}=1, M 3$. Dimensions values of grid area are equal to:

$$
S_{1}=M 1=2 ; S_{2}=M 2=25 ; S_{3}=M 3=104 .
$$

Thus, the number of nodes in the grid two-layer area is equal to:

$$
N_{U X}=M 1 \times M 2 \times M 3=2 \times 25 \times 104=5200 .
$$

Accordingly, the number of nonlinear equations is the system of:

$$
K=3 \times N_{U X}=3 \times 5200=15600
$$

equations without consideration the imposed boundary conditions.

The grid area describes a discrete finite element model of $24 \times 103=2472$ finite element elements, including cavities with boundaries, which is determined 
by the grid coordinates $S_{1}, S_{2}$, initial and final nodes of the regular area respectively 1,$63 ; 2,64 ;$ i 1,$64 ; 3,104$. These coordinates are determined the permanent cavity for both variants of the calculation scheme.

The transformed cavity, which models the pit development of the building underground part, in the discrete model is determined by the corresponding nodal grid coordinates; within the regular domain boundary nodes of inclusions of soil layers of multilayered half-space are described, as well as the inclusions elements of the enclosures "walls in soil" and foundation structures.

The geometric dimensions of the estimated half-space are $41 \times 150 \mathrm{~m}$, the thickness of the half-space is equal $50 \mathrm{~cm}$.

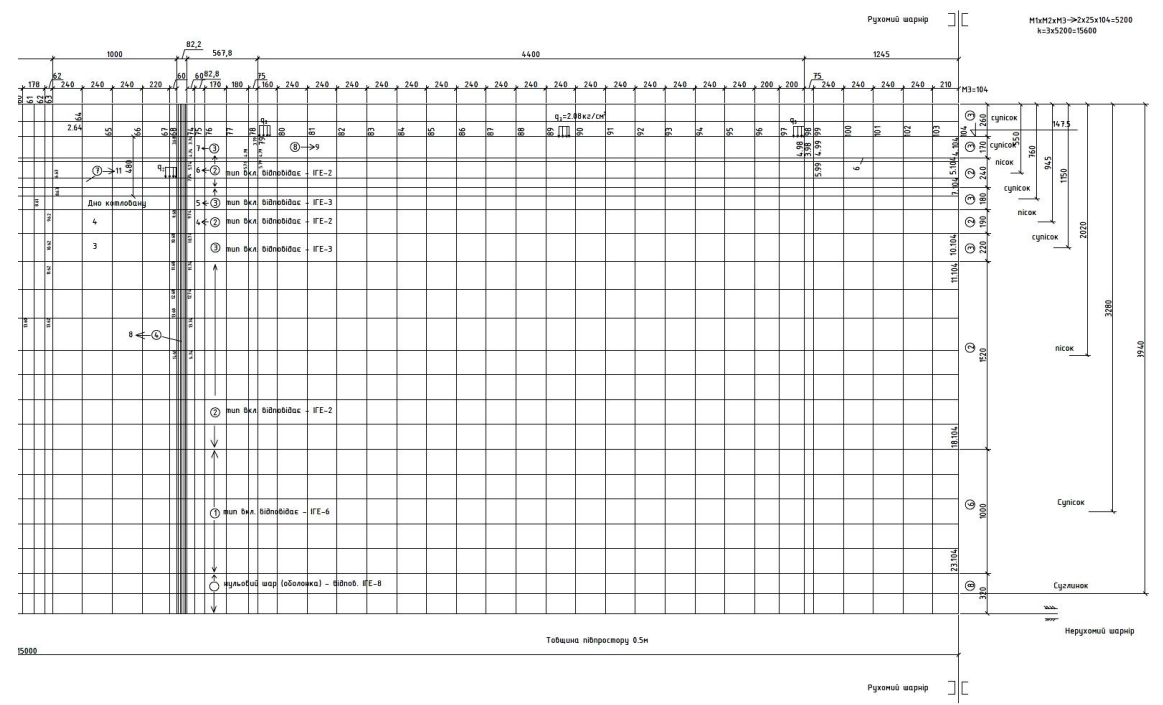

Fig. 2. Discrete model and calculation scheme of half-space:

influence on the stress-strain state of half-space from a 5-storey building with a free pit

\section{Results of numerical research of a discrete model of combined half- space.}

The accepted calculation variant of interaction the fencing structures and the existing building foundations with soil half-space at a free pit is a classic for solving this problematic task, and, as a rule, the most dangerous in terms of the stability of the pit slope. But in this version of the problem statement, this option was quite safe, because the pit depth is due to the difference planning mark on $2,5 \mathrm{~m}$ is only $4,5 \mathrm{~m}$ and the active pressure from such a slope prism was insignificant.

The calculation is implemented at three values of the depth of the "wall in the soil" $-17.2 \mathrm{~m}, 12.6 \mathrm{~m}$ i $10.3 \mathrm{~m}$. Based on these results, the corresponding appropriate plots of, settlements, and internal efforts in the wall-in-soil structure elements have been constructed, that are shown on Fig. 3, 4, 5. 


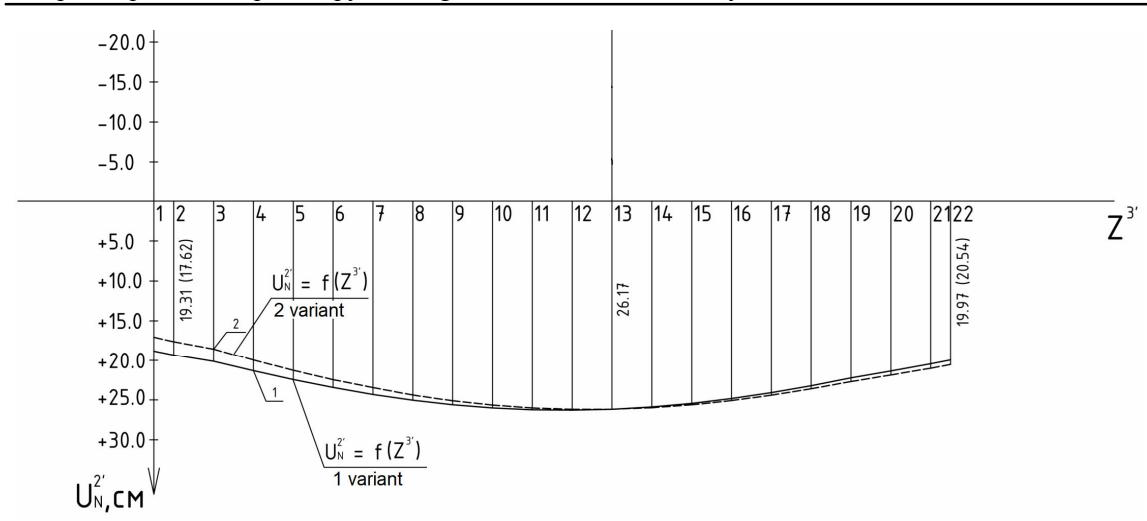

Fig. 3. Plot of nodal displacements (vertical sediments) placed on the sole of the foundation from additional external loads under different conditions:

1 variant - before developing of the pit; 2 variant - after development of the pit to the mark of the free bottom (before arranging the pile foundation under a new tall building)

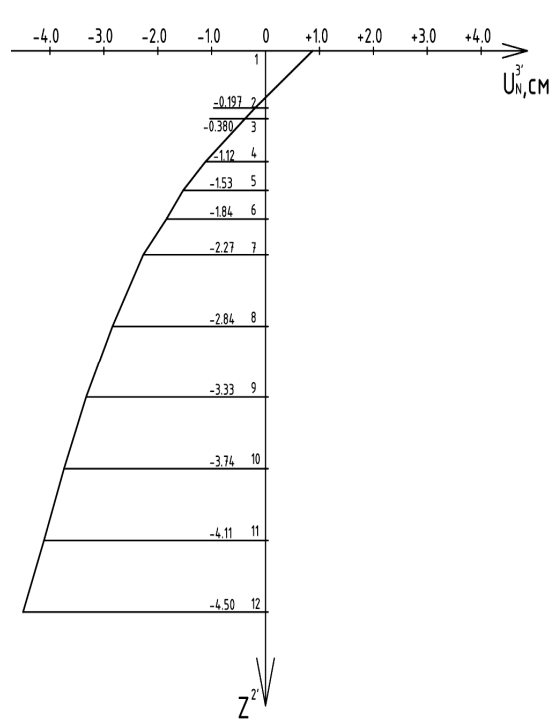

Fig. 4. Plot of transverse deflections "wall-in-soil"

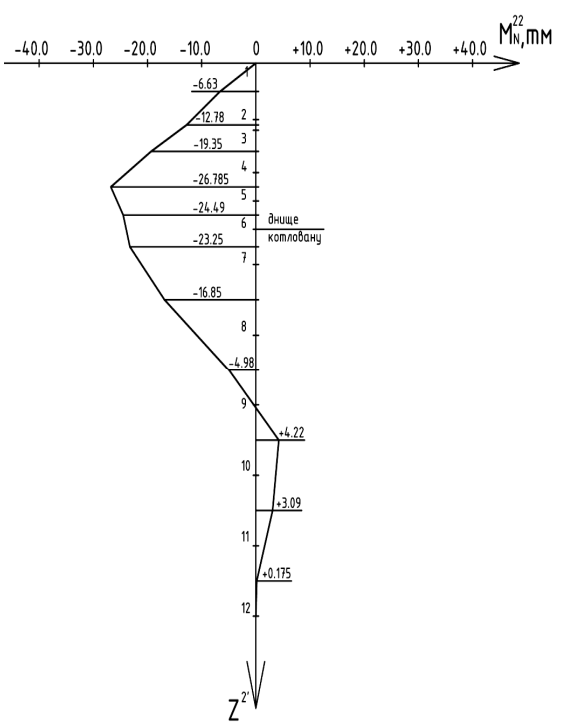

Fig. 5. Plot of bending moments in cross section "wall-in-soil"

According the character graphics displacements of the free pit bottom there soil bulging, but insignificant - in the center of the pit

$U_{1165}^{2}=-10,15 \mathrm{~cm}$.

At the width of the pit $81.23 \mathrm{~m}$ such output is negligible. According to the plot of vertical movements of the sole of the foundation of the existing 5-storey 
building it can be seen that the average uneven subsidence in the half-span of the foundation length is:

$$
\frac{4,56}{2200} \cong 0,0021<0,0024
$$

that is less than the standard non-uniform clockwise rotation, how the sliding prism moves under active pressure.

The stress-strain state of the wall-in-soil structure is illustrated by a plot of transverse deflections (Fig. 4) and plot of bending moments in cross section "wall-in-soil" (Fig. 5).

From the analysis of the nodes displacements located on the vertical face of the wall-in-soil (retaining wall) construction, it can be concluded, that the transverse displacements of the retaining wall occur as a significant whole by rotating it substantially as a whole clockwise. In such a turn, the internal forces are insignificant within 50\% margin of safety of the retaining wall strength.

\section{Conclusions and recommendations}

The task of pressure changing on the enclosure structure in time and determining the change in the stress-strain state of the enclosure structure and the existing dwelling house basis has been solved.

The change in the 5-storey building foundation deformation has been determined, that is, the oscillation of the soil foundation and the maximum amplitude of uneven subsidence of the existing building foundations, that is a criterion for the influence determining of adjacent construction in an urban area on the soil bases condition and foundations of adjacent buildings.

Results of scientific researches have shown that according to the results of numerical calculations it is enough to design a protective screen of enclosing structures to a depth of 10-12 m, but according to the results of the second variant, in the presence of fluctuations of active and passive pressure on the enclosure "wall in soil" it is necessary to design the screen to a depth of $17.0 \mathrm{~m}$, with the maximum amplitude of non-uniform sediments almost approaching the limit relative normative value.

The impact of the new building on the existing nearby five-story apartment building was significant enough. There is a change in pressure on the protective enclosure, which causes the maximum permissible subsidence of the foundations bottom and the heeling change.

The amount of sedimentation will not cause the development of cracks, but a protective screen - the enclosure structure in conjunction with this building should be arranged at a depth of at least $17.0 \mathrm{~m}$, and a diameter of at least $600 \mathrm{~mm}$, with appropriate seams of settlement.

The recommendations made can be taken into account when making design decisions considering the possible dangers from the impact of new multi-storey building for scientific substantiation of the necessary measures of engineering preparation of new construction [6]. In the future proposed methodology of scientific substantiation of measures for engineering preparation of territories and forecasting of their possible consequences, on the basis of the analysis of 
numerical studies of the stress state and the assessment of the stability of the real objects basics by generalized design parameters, will allow to build principles of reconstruction of urban territories with dense development and difficult geological conditions and provide appropriate guidance to determine the impact of the reconstruction and the extent of the necessary engineering preparation to protect the site and preserve existing construction.

\section{REFERENCES}

1. Bazhenov V.A., 2002. The Moment Finite-Element Scheme in Problems of Nonlinear Continuum Mechanics / V.A. Bazhenov, A.S. Sakharov, V.K. Tsykhanovskii // International Applied Mechanics. - Vol.38, Iss.6. - Ps. 658-692. [https://link.springer.com/article/10.1023/A\%3A1020424710876]

2. Bazhenov V.A., Tsykhanovskii V.K., Kyslookyi V.M., 2000. Metod skinchennykh elementiv u zadachakh neliniynoho deformuvannya tonkykh ta myakykh obolonok. (Finite element method in problems of nonlinear deformation of thin and soft shells). - Kyiv National University of Construction and Architecture. -386 c. (ukr)

3. Prusov D.E., 2009. Problemy proektuvannya ohorodzhuyuchykh konstruktsiy hlybokykh kotlovaniv v umovakh shchilnoyi zabudovy (Problems of designing enclosing structures of deep excavations in the dense housing conditions) / D.E. Prusov // Urban and territorial planning. Kyiv National University of Construction and Architecture. - Vol.37. - Ps.121-130. (ukr)

4. Prusov D.E., 2012. Numerical Research of the Retaining Constructions During Reconstruction of the Transport Structures / D.E. Prusov // Transport (Lithuania). - Volume 27, Issue 4. Ps. 357-363. [https://journals.vgtu.lt/index.php/Transport/article/view/4953]

5. Prusov D.E., 2014. Stress-Strain State of a Combinational Soil Half-Space During Reconstruction / D.E. Prusov // International Applied Mechanics. - Volume 50, Issue 2, - Pp $141-149$.

[https://ink.springer.com/article/10.1007/s10778-014-0618-x]

6. Prusov D.E., 2014. The System of Risk Assessment Criteria and Consequences Prediction of Urban Areas Transformation / D.E. Prusov // Proceedings of the National Aviation University. - Vol.61, No.4. - Ps. 116-120.

[http://jrnl.nau.edu.ua/index.php/visnik/article/view/7601]

7. Utility Model Patent, 2011. Sposib urakhuvannya zminy $\mathrm{z}$ hlybynoyu kharakterystyk mitsnosti neodnoridnoho hruntovoho pivprostoru (The method for account change in depth of strength characteristics of non-uniform soil semi-space) / Inventors: Tsykhanovskii V.K., Prusov D.E. // Utility Model Patent No.59066, Ukraine, MPK G01N 33/24 (2006.01), Bull. No.9, 2011. (ukr)

8. Tsykhanovskii V.K., 2004. Metod skinchennykh elementiv u zadachakh doslidzhennya neodnoridnoho pivprostoru z urakhuvannyam heometrychnoyi i fizychnoyi neliniynosti (Finite element method in problems of investigation of inhomogeneous half-space taking into account geometric and physical nonlinearity) / Tsykhanovskii V.K., Prusov D.E.// Strength of Materials and Theory of Structures - Kyiv National University of Construction and Architecture. - Vol.75.- Ps. 87-98. (ukr)

Стаття надійшла до редакиії 01.01.2020

\section{Prusov D.E.}

SCIENTIFIC SUBSTANTIATION OF ENGINEERING PREPARATION MEASURES DUE TO THE INFLUENCE OF CONSTRUCTION IN THE DENSE BUILDING CONDITIONS

The method of studying the stress-strain state of reinforcement structures of combined soil massifs has been proposed with the geometric and physical nonlinearity in the formulation of the problem based on the nonlinear theory of elasticity and plasticity of the soil. The study of the stressdeformed state of the computational domain from the standpoint of the mechanics of the deformed solid body had been carried out, using algorithms for solving the problems of the theory of elasticity and plasticity, with the construction of universal computational models of the combined half-space, 
that allows to determine more reasonably the magnitude of the stress-strain state of complex soil bases in interaction with the reinforcement structures, the surrounding buildings foundations and the whole complex of the surrounding buildings structures. The influence of new construction on the condition of soil bases and foundations of adjacent buildings had been evaluated by determining the change of pressure on the reinforcement structure and determining the stress-strain state change of this structure and the foundation of the existing house. The change in the deformation of the foundation of the existing building, ie the oscillation of the soil foundation and the maximum amplitude of uneven subsidence of the foundations of the existing building have been determined. Each formulation of the problem had to include its own reliability analysis and a specific approach that requires numerical modeling and development of appropriate measures to scientifically substantiate engineering preparation measures in dense building. Further design of protective reinforcement structures for new construction under the conditions of the building reconstruction has carried out considering the impact on the existing buildings and structures and the adjacent soil mass of different stages of construction, begining with the arrangement of protective reinforcement structures, the development of a excavation due to the effect of unloading the foundation, and the sequence of erection of engineering structures.

Keywords: new construction, scientific substantiation, stress-strain state, reinforcement structures, engineering preparation.

\section{Прусов Д.Е.}

\section{НАУКОВЕ ОБГРУНТУВАННЯ ЗАХОДІВ 3 ІНЖЕНЕРНОЇ ПІДГОТОВКИ 3 УРАХУВАННЯМ ВПЛИВУ БУДІВНИЦТВА В УМОВАХ ЩІЛЬНОЇ ЗАБУДОВИ}

Запропонована методика дослідження напружено-деформованого стану конструкцій укріплень грунтових масивів з урахуванням геометричної і фізичної нелінійності в постановці задачі на основі нелінійної теорії пружності і пластичності грунтів. Виконано дослідження напружено-деформованого стану розрахункової області 3 позицій механіки деформованого твердого тіла, із застосуванням алгоритмів розв'язання задач теорії пружності і пластичності, 3 побудовою універсальних розрахункових моделей комбінованого півпростору, що дозволяє більш обгрунтовано визначати величину напружено-деформованого стану складних грунтових основ, які перебувають у взаємодії з огороджувальними конструкціями укріплень, фундаментів прилеглих будинків і всього комплексу споруд навколишньої забудови. Проведено оцінку впливу нового будівництва на стан основ і фундаментів суміжних будівель шляхом визначення зміни тисків на огороджувальну конструкцію у часі та визначенні зміна напружено-деформованого стану самої огороджувальної конструкції і основи існуючого житлового будинку. Визначена зміна деформування основи існуючого будинку, тобто коливання грунтової основи та максимальна амплітуда нерівномірного осідання фундаментів існуючої будівлі. Кожна постановка задачі повинна включати власний аналіз на достовірність i особливий підхід, який вимагає проведення чисельного моделювання та розробки відповідних заходів для наукового обгрунтування заходів 3 інженерної підготовки будівництва в умовах щільної забудови. Подальше проектування захисних огороджувальних конструкцій під нове будівництво в умовах реконструкції забудови проводиться 3 урахуванням впливу на існуючі будівлі та споруди і прилеглий грунтової масив різних етапів будівництва, починаючи з улаштування захисних огороджувальних конструкцій, розробки котловану 3 урахуванням ефекту розвантаження основи, та послідовності зведення інженерних конструкцій.

Ключові слова: нове будівництво, наукове обгрунтування, напружено-деформований стан, конструкції укріплення, інженерна підготовка.

\section{УДК 539.3;624.1}

Прусов Д.Е. Наукове обгрунтування заходів 3 інженерної підготовки 3 урахуванням впливу будівництва в умовах щільної забудови / Опір матеріалів і теорія споруд: наук.-тех. збірн. - К.: КНУБА, 2020. - Вип. 104. - С. 229-241.

Запропоновано методику дослідження напружено-деформованого стану конструкиій укріплень трунтових масивів та проведено оцінку впливу нового будівництва для наукового обтрунтування необхідних заходів інженерної підготовки нового будівництва та рекомендацій щуодо прийняття проектних рішень з урахуванням можливих небезпек. Іл. 5. Бібліогр. 8 назв. 
UDC 539.3;624.1

Prusov D.E. Scientific substantiation of engineering preparation measures due to the influence of construction in the dense building conditions / Strength of Materials and Theory of Structures: Scientific-and-technical collected articles. - K.: KNUBA, 2020. - Issue 104. - P. 229-241.

The method of studying the stress-strain state of strengthening structures of combined soil massifs has been proposed and the impact of new construction has been evaluated for scientific substantiation of necessary engineering preparation measures and recommendations for making design decisions due to possible dangers.

Fig. 5. References 8 items.

Автор (вчена ступень, вчене звання, посада): доктор технічних наук, старший науковий співробітник, завідувач кафедри БІТ Інституту інновачійної освіти КНУБА, ПРУСОВ Дмитро Едуардович.

Адреса робоча: 03037, Украӥна, м. Київ, вул. Освіти, 4. Інститут інновачійної освіти Київського начіонального університету будівниџтва і архітектури, ПРУСОВ Д.Е.

Тел.: +38 (044) 244-96-63, (044) 245-48-56

E-mail: prusov.de@knuba.edu.ua

ORCID ID: 0000-0002-1720-2798

Author (degree, academic title, position): Doctor of Technical Sciences (Prof.Dr.Habil.), Senior Researcher, Head of the Department, Institute of Innovative Education of the Kyiv National University of Construction and Architecture, PRUSOV Dmytro Eduardivych.

Address: 03037, Ukraine, Kyiv, Osvity str., 4. The Institute of Innovative Education of the Kyiv National University of Construction and Architecture, PRUSOV D.E.

Phone: +38 (044) 244-96-63, (044) 245-48-56

E-mail: prusov.de@knuba.edu.ua

ORCID ID: 0000-0002-1720-2798 